\title{
Robert Kuwałek, Obóz zagłady w Betżcu, Lublin: Państwowe Muzeum na Majdanku, 2010, 279 s.
}

Wyjątkowość hitlerowskiej „fabryki śmierci” sprawiła, że historycy, filozofowie i politolodzy „skupili się na obozach zagłady i na wykorzystaniu kolei do przewiezienia Żydów do Auschwitz-Birkenau oraz do Sobiboru, Chełmna, Bełżca, Majdanka i Treblinki [...]"1. Ray Brandon i Wendy Lower określili to zjawisko mianem „syndromu Auschwitz”, który wpłynął nie tylko na kształt literatury przedmiotu, lecz także pamięci o Zagładzie. Istotnie, na temat obozu Auschwitz-Birkenau powstała obszerna literatura ${ }^{2}$. W ostatnich latach ukazało się również kilka ważnych monografii obozów koncentracyjnych i obozów pracy założonych na ziemiach polskich. Opublikowano też badania dotyczące zagłady Żydów w Generalnym Gubernatorstwie ${ }^{3}$. Natomiast obozy zagłady w Chełmnie nad Nerem, Bełżcu, Sobiborze i Treblince nie doczekały się większych opracowań. Tym ważniejsza jest książka

${ }^{1}$ Ray Brandon, Wendy Lower, Introduction [w:] The Shoah in Ukraine: History, Testimony, Memorialization, red. Ray Brandon, Wendy Lower, Bloomington: University of Indiana Press, 2010, s. 6. Owa fascynacja miała przyczynić się do luk w badaniach nad Zagładą w poszczególnych krajach i na płaszczyźnie regionalnej. Na ten temat zob. Dan Stone, Beyond the „Auschwitz Syndrome”: Holocaust Historiography after the Cold War, „Patterns of Prejudice” 2010, t. 44, nr 5, s. 454-468.

${ }^{2}$ Zob.: Anatomy of the Auschwitz Death Camp, red. Yisrael Gutman, Michael Berenbaum, Bloomington: Indiana University Press, 1994; Auschwitz 1940-1945. Węzłowe zagadnienia z dziejów obozu, t. 1: Założenie i organizacja obozu, t. 2: Więźniowie - życie i praca, t. 3: Zagłada, t. 4: Ruch oporu, t. 5: Epilog, red. Wacław Długoborski, Franciszek Piper, Oświęcim-Brzezinka: Wydawnictwo Państwowego Muzeum, 1995; „... płakaliśmy bez łez...”. Relacje bytych więźniów żydowskiego Sonderkommando z Auschwitz, red. Gideon Greif, tłum. Jan Kapłon, Warszawa-Oświęcim: ŻIH i Muzeum Auschwitz-Birkenau, 2001; Małgorzata Preuss, Architekci Zagłady. Analiza funkcjonowania Centralnego Zarzadu Budowlanego w KL Auschwitz-Birkenau, „Zagłada Żydów. Studia i Materiały” 2006, nr 2, s. 374-384; David Bertolini, The Architecture of Auschwitz-Birkenau and the Nazi Fantasy, „Holocaust Studies” 2008, t. 14, nr 3, s. 25-60; Eliezer Schwartz, The Role of IG Farben-Auschwitz in the Contruction of the Birkenau Extermination Camp, „Yad Vashem Studies” 2010, t. 38, nr 2, s. 11-45; Debórah Dwork, Robert Jan van Pelt, Auschwitz. Historia miasta i obozu, tłum. Katarzyna Bażyńska-Chojnacka, Piotr Chojnacki, Warszawa: Świat Książki, 2011.

${ }^{3}$ Literatura przedmiotu na temat obozu Auschwitz jest szczególnie obfita. Na temat innych obozów zob. Anna Ziółkowska, Obozy pracy przymusowej dla Żydów w Wielkopolsce w latach okupacji hitlerowskiej (1941-1945), Poznań: Wydawnictwo Poznańskie, 2005; Ryszard Kotarba, Niemiecki obóz w Ptaszowie, 1942-1945, Warszawa-Kraków: IPN, 2009; Tomasz Kranz, Zagłada Żydów w obozie koncentracyjnym na Majdanku, Lublin: Państwowe Muzeum na Majdanku, 2007; Christopher R. Browning, Remembering Survival: Inside a Nazi Slave-Labor Camp, New York-London: W.W. Norton and Company, 2010. Na temat losu Żydów w GG zob. Yitzhak Arad, Belzec, Sobibor, Treblinka: The Operation Reinhard 
Roberta Kuwałka Obóz zagłady w Bełżcu. Kuwałkowi udało się wypełnić wiele luk w naszej wiedzy o tym ośrodku zagłady. Jednocześnie jego książka uświadamia, jak wiele pytań pozostaje nadal bez odpowiedzi.

Autor zebrał materiały i uporządkował wiedzę na temat okoliczności towarzyszących decyzji o stworzeniu ośrodka zagłady w Bełżcu i wyodrębnił zasadnicze etapy jego funkcjonowania od marca do grudnia 1942 r., kiedy do obozu wysyłano transporty Żydów, oraz w okresie od grudnia 1942 do końca marca 1943 r., kiedy palono tam zwłoki zamordowanych wcześniej ofiar. Na podstawie dostępnych źródeł archiwalnych i relacji świadków Kuwałek szacuje, że w obozie zamordowano około 450 000-500 000 Żydów. Jego zdaniem, wśród ofiar komór gazowych Bełżca znalazła się ponadto trudna do ustalenia liczba Romów. Autor nie ograniczył się przy tym do opisania samego obozu i jego załogi, ale starał się zanalizować doświadczenia żydowskich ofiar w drodze do obozu. Przedstawił również powojenne losy terenu dawnego obozu i powolne przejście od społecznej niepamięci do pierwszych form upamiętniania jego ofiar.

Nowa monografia obozu zagłady w Bełżcu powstała w wyniku kwerend w archiwach polskich, niemieckich, izraelskich i amerykańskich. Kuwałek korzystał z różnorodnych źródeł: materiałów z polskiego śledztwa prowadzonego w latach 1945-1946 przez Okręgową Komisję Badania Zbrodni Niemieckich w Lublinie oraz dokumentacji ze śledztwa i niemieckich procesów sądowych członków załóg obozów zagłady, a także z relacji ocalałych Żydów i polskich świadków, jak też archiwaliów podziemia polskiego. Wziął również pod uwagę wyniki badań archeologicznych prowadzonych na terenie Muzeum-Miejsca Pamięci w Bełżcu, którym kierował w latach 2004-2007. Cenne są uwagi autora na temat wartości zeznań polskich świadków, składanych w ramach powojennego śledztwa. To właśnie owe zeznania umożliwiły ustalenie, kiedy na terenie przyszłego obozu powstały pierwsze komory gazowe (s. 38-39). Praca Kuwałka dowodzi, jak cennym źródłem są relacje ocalałych Żydów, zawierające często szczegóły, które potwierdziły najnowsze badania archeologiczne - na przykład liczbę masowych grobów zanotowaną przez Rudolfa Redera.

W pierwszych rozdziałach książki Kuwałek przedstawia sytuację ludności żydowskiej w Generalnym Gubernatorstwie od wybuchu drugiej wojny światowej do jesieni 1941 r., kiedy rozpoczęła się budowa obozu zagłady w Bełżcu. Opisuje narastającą izolację fizyczną i mentalną Żydów w wyniku represji stosowanych przez okupantów niemieckich oraz procesu gettoizacji, zwracając przy tym uwagę na to, że „każde nowe prawo usuwało Żydów całkowicie poza nawias człowieczeństwa” (s. 18). Odwołując się do istniejącej literatury przedmiotu, autor porządkuje wiadomości na temat początków obozu zagłady w Bełżcu w kontekście decyzji o eksterminacji Żydów w GG. Wskazuje na radykalizację polityki niemieckiej wobec Żydów na ziemiach polskich. Żydzi w dystrykcie Galicja, przyłączonym do GG po ataku

Death Camps, Bloomington: Indiana University Press, 1999; Akcja Reinhardt. Zagłada Żydów w Generalnym Gubernatorstwie, red. Dariusz Libionka, Warszawa: IPN, 2004. 
niemieckim na ZSRR, „doświadczyli masowego mordu jeszcze przed początkiem planowanej totalnej zagłady, znanej pod późniejszym kryptonimem operacja «Reinhardt»” (s. 27). Natomiast zarządzenie Hansa Franka z 15 października 1941 r. o zakazie opuszczania dzielnic żydowskich przez Żydów pod karą śmierci „stanowiło [...] niewątpliwie wstęp do rozpoczęcia planowej polityki zagłady” (s. 21).

Wprawdzie książka Kuwałka ma charakter monograficzny, niemniej odnosi się do szerszego pytania o genezę i krystalizację programu zagłady Żydów na etapie budowy obozu i w pierwszych miesiącach jego funkcjonowania. Autor dowodzi, że decyzje o eksterminacji Żydów i budowie obozu w Bełżcu zapadły na przełomie września i października 1941 r. Rozpoczęcie budowy obozu w Sobiborze koło Włodawy wskazuje, że „plany uruchomienia ośrodka natychmiastowej śmierci w Bełżcu nie miały charakteru tylko lokalnego. Gdyby tak było, nie istniałaby konieczność tworzenia drugiego takiego miejsca w tak krótkim czasie” (s. 32). Co więcej, powstanie obozu w Bełżcu miało związek z szerszymi planami nazistowskimi i deportacjami Żydów z Rzeszy oraz Protektoratu Czech i Moraw. Szczegółowe rozważania na temat obozu wskazują też na wewnętrzne sprzeczności w eksterminacyjnej polityce niemieckiej. Choć, jak dowodzi Kuwałek, jako pierwsi mieli zginąć w Bełżcu przede wszystkim Żydzi uznani za niezdolnych do pracy, ofiarami akcji w Lublinie wiosną 1942 r. padli również Żydzi zatrudnieni w niemieckich przedsiębiorstwach (s. 96-97).

Historyk przekonująco tłumaczy, dlaczego obóz zagłady umieszczono w Bełżcu. Decyzja, którą musiał podjąć Odilo Globocnik, została podyktowana względami praktycznymi. Miejscowość położona na granicy dystryktów: lubelskiego, galicyjskiego i krakowskiego i przy ruchliwej linii kolejowej, miała gotową do użytku bocznicę kolejową. Ponadto Bełżec był znany wcześniej Globocnikowi, gdyż w 1940 r. funkcjonował tam obóz pracy (s. 37-40). Decyzja zapadła pomimo położenia, które nie zapewniało rzeczywistej izolacji, a co za tym idzie zachowania tego, co działo się w obozie, w ścisłej tajemnicy. Autor skrupulatnie odtwarza etapy budowy obozu, rozpoczętej 1 listopada 1941 r., początkowo przez polskich robotników przy udziale strażników z obozu szkoleniowego SS w Trawnikach, a następnie przez samych więźniów żydowskich z Lubyczy Królewskiej. Na podstawie zeznań polskich świadków, strażników, świadectw ocalałych i badań archeologicznych opisuje topografię bełżeckiego ośrodka zagłady, podzielonego na obóz dolny, w którym przyjmowano transporty deportowanych Żydów, i obóz górny, gdzie dokonywała się ich eksterminacja. Opisując mechanizmy masowej zagłady, Kuwałek stawia pytania, na które dostępne materiały nie pozwalają udzielić jednoznacznej odpowiedzi: o procedurę przyjętą dla zmuszanych do rozebrania się mężczyzn i kobiet z dziećmi w pierwszym etapie działania obozu oraz o położenie nowych komór gazowych, zainstalowanych po jego gruntownej przebudowie na przełomie czerwca i lipca 1942 r. Niejasne jest również przeznaczenie betonowych krążków, odnalezionych na terenie obozu, które mogły służyć jako pokwitowania za kosztowności i pieniądze.

Kuwałek poświęca wiele miejsca sprawcom - sztabowi operacji „Reinhardt”, niemieckiej załodze obozu i jednostkom pomocniczym. Poddaje krytycznej analizie 
powojenne zeznania członków SS służących w obozach zagłady, wśród których znaleźli się - używając kategorii Raula Hilberga: „fanatycy, zwyrodnialcy i ludzie

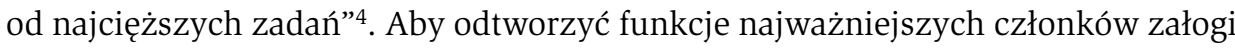
w Bełżcu (spośród ustalonych 37 nazwisk), konfrontuje je z zeznaniami polskich świadków oraz relacją ocalałego - Rudolfa Redera. Charakteryzuje przy tym metody zastosowane przez pierwszego komendanta obozu w Bełżcu Christiana Wirtha, jego następcę Gottlieba Heringa, zastępcę komendantów Gottfrieda Schwarza i pełniącego funkcję adiutanta Josefa Oberhausera. Wskazuje zarazem na ścisły związek załogi obozu z operacją „eutanazji” na terenie Rzeszy w latach 1939-1941. Dowodzi również, że Bełżec był swoistym laboratorium - jego załoga pełniła podobne funkcje najpierw w Bełżcu, a następnie w innych obozach zagłady, przenosząc zdobyte wcześniej doświadczenia.

W osobnym rozdziale opisuje formacje pomocnicze w obozie zagłady w Bełżcu, przez które przewinęło się wedle jego szacunków około 400 osób. W odróżnieniu od Yitzhaka Arada, podkreślającego ochotniczy charakter tych formacji, przypomina, że ich współpraca z Niemcami nie była „do końca dobrowolna. Kandydatów wybierano przede wszystkim z obozów jenieckich, gdzie panowały potworne warunki bytowe i jeńcy sowieccy umierali z głodu tysiącami. Chęć wyrwania się z takich miejsc stanowiła dominujący powód, który motywował tych ludzi do wstąpienia na służbę niemiecką" (s. 77). Strażnicy, którzy przybywali do Bełżca z obozu szkoleniowego SS w Trawnikach, stawali się brutalnymi uczestnikami zagłady Żydów. Autor tłumaczy ucieczki strażników w 1943 r. narastającą obawą o poniesienie odpowiedzialności po klęsce Trzeciej Rzeszy oraz strachem przed Niemcami, którzy mogliby chcieć usunąć świadków zbrodni.

Kuwałek stawia w swojej monografii trudne pytania o charakter relacji miejscowej ludności ze strażnikami i jej stosunek do zbrodni popełnianych w obozie. Autor $z$ jednej strony ostrożnie ocenia udział polskich robotników, opłacanych przez okupanta za ich pracę przy budowie obozu: „Doszukiwanie się tutaj chęci zdobycia specjalnego zarobku wydaje się bezpodstawne, zwłaszcza że ludzie ci nie wiedzieli, jaki obiekt budują" (s. 41-42). Z drugiej zaś wskazuje na powszechne zjawisko handlu z wachmanami i rodzaj swoistej symbiozy, która trwała jeszcze po zamknięciu obozu, kiedy jego teren był przeszukiwany przez okoliczną ludność (s. 88-90, $145,163)$.

Autor nie ogranicza się do opisu samego obozu, jego załogi i metod masowej eksterminacji. Stara się również drobiazgowo odtworzyć transporty do Bełżca z Lublina i innych gett dystryktu lubelskiego oraz z Galicji, ze Lwowa i okolic, a także z dystryktu krakowskiego. Podejmuje też kwestię nieludzkich warunków, w jakich deportowano Żydów, oraz prowadzonej przez Niemców ewidencji: „Nikt nie sporządzał list deportacyjnych, nigdy więc nie poznamy większości nazwisk ofiar. W trakcie załadunku transportu policjanci lub SS-mani, którzy byli odpowiedzial-

\footnotetext{
${ }^{4}$ Raul Hilberg, Sprawcy, ofiary, świadkowie. Zagłada Żydów 1933-1945, tłum. Jerzy Giebułtowski, Warszawa: Centrum Badań nad Zagładą Żydów i Cyklady, 2007, s. 85.
} 
ni za likwidację gett lub deportacje do Bełżca, po prostu liczyli osoby wpychane do wagonów, a po ich zamknięciu kredą zapisywali na ścianach liczbę deportowanych” (s. 120).

Jeden z najbardziej poruszających rozdziałów książki poświęcony jest mechanizmom zagłady w obozie. Proces uśmiercania ofiar został skrócony do zaledwie 2-3 godzin od momentu przybycia pociągu do złożenia ciał zamordowanych Żydów w masowych grobach. Pierwszemu komendantowi obozu udało się uśpić czujność deportowanych, co było możliwe w początkowym okresie funkcjonowania obozu, kiedy nie zdawali sobie oni sprawy z tego, co ich czeka. Z czasem brutalne traktowanie ludzi z transportów uniemożliwiło jakikolwiek opór wobec przeprowadzanej w błyskawicznym tempie eksterminacji. Zagładzie Żydów towarzyszyła dobrze zorganizowana grabież ich mienia jeszcze przed odjazdem transportów i po ich przybyciu do Bełżca. Powołując się na dokument znaleziony w 2009 r. w zbiorach archiwalnych Państwowego Muzeum na Majdanku, Kuwałek dowodzi, że w Bełżcu prowadzono szczegółową rejestrację przedmiotów odbieranych ofiarom, nawet rzeczy osobistych, takich jak szczoteczki do zębów czy grzebienie (s. 140).

Autor stara się również odtworzyć stan wiedzy na temat losu transportów wysłanych do obozu wśród Żydów pozostałych w gettach, wśród okolicznej ludności oraz w strukturach Polskiego Państwa Podziemnego. Co wreszcie mogli wiedzieć Żydzi wiezieni w nieludzkich warunkach na zagładę. Opierając się na powojennych zeznaniach świadków, Kuwałek stwierdza, że „po przybyciu pierwszych transportów w Bełżcu stało się prawdopodobnie powszechnie wiadomym faktem, że nie jest to obóz przejściowy i że przywożeni do niego Żydzi kierowani są tutaj na zagładę” (s. 178). Przeznaczenia obozu domyślali się też kolejarze polscy prowadzący transporty do stacji Bełżec i pasażerowie pociągów pasażerskich przejeżdżających przez tę stację. Natomiast wiedza Niemców „na temat obozów zagłady czy samego obozu w Bełżcu była powszechna nie tylko w jego najbliższych okolicach, pomijając już fakt, że w obozie zagłady w Bełżcu bywali policjanci, którzy eskortowali transporty z deportowanymi Żydami z najdalszych okolic i doskonale wiedzieli, co się dzieje z ludźmi, których tam przywieziono” (s. 214). Zbrodnie popełnione w Bełżcu nie mogły być zresztą tajemnicą ze względu na smród spalanych zwłok ofiar, który dochodził nawet do miejscowości oddalonych od obozu. Dla ludności gett źródłem informacji o Bełżcu byli Żydzi, którym udało się uciec z pierwszych transportów. Autor podkreśla jednak, że docierały one jedynie do członków i najbliższego kręgu Judenratu w Lublinie, Zamościu czy Lwowie. Z kolejnymi deportacjami świadomość o przeznaczeniu obozu w Bełżcu stawała się coraz powszechniejsza. Wiedza o losie transportów wpływała na zachowania Żydów pozostałych w gettach, do których dotarli uciekinierzy: „Jesienią 1942 r., gdy o obozie zagłady w Bełżcu wiedziano dość powszechnie w gettach Małopolski Wschodniej, ludzie szli do transportu nie tyle $z$ bagażami, ile $z$ narzędziami, za pomocą których mogliby wybijać dziury w podłogach lub ścianach i uciekać” (s. 187). Im dalej od Bełżca, tym mniejsza była szansa, by do Żydów dotarły wiadomości o prawdziwym przeznaczeniu transportów. Widać to wyraźnie, gdy porównamy relacje z gett w Galicji 
z relacjami z dystryktu krakowskiego. Wraz ze wzrostem świadomości na temat tego, co oznaczają deportacje do Bełżca, załoga obozu spotykała się z coraz częstszymi przypadkami stawiania oporu, przede wszystkim biernego, przy wysiadaniu z wagonów na rampie i po rozkazie rozbierania się (s. 135).

Autor stara się odtworzyć życie codzienne nielicznej grupy Żydów, którzy w Bełżcu zostali wybrani do pracy. Opisuje poszczególne grupy więźniów, którym przydzielano zadania przy obsłudze załogi obozowej i w procesie eksterminacji ich współbraci. Podaje informacje o próbie zorganizowania zbrojnego oporu oraz przypadki sabotażu, kiedy „więźniowie żydowscy specjalnie pozostawiali gwiazdy Dawida na poszczególnych sztukach odzieży [ofiar] lub kosztowności w kieszeniach, by dać świadectwo rozgrywającej się w Bełżcu zbrodni” (s. 141).

W rozdziale zatytułowanym „Pół wieku zapomnienia” Kuwałek podejmuje ważną kwestię polskiej pamięci/niepamięci o Zagładzie ${ }^{5}$. Amnezję na temat charakteru miejsca zagłady autor przekonująco tłumaczy względami politycznymi. Mimo śledztwa w sprawie dewastacji terenu obozu prowadzonego w latach 1945-1946 przez Okręgową Komisję Badania Zbrodni Niemieckich w Lublinie, mimo wysiłków podejmowanych przez Centralny Komitet Żydów w Polsce obóz został szybko zapomniany. Organizacje żydowskie skupiły swoje wysiłki na upamiętnieniu Majdanka i Auschwitz-Birkenau. Jedyni żydowscy świadkowie zbrodni zniknęli - Chaim Hirszman został zamordowany w marcu 1946 r., Rudolf Reder zaś wyemigrował z Polski w 1950 r. Oficjalna polityka pamięci podkreślała martyrologię narodu polskiego. Dlatego też na pierwszym pomniku, postawiony w Bełżcu dopiero w 1963 r., zabrakło informacji, że ofiarami obozu byli Żydzi. Być może za milczeniem wokół obozu zagłady w Bełżcu mogła stać nie tylko próba nadania mu polskiego charakteru, lecz także fakt, iż znaczną część jego ofiar stanowili Żydzi obywatele polscy z terenów, które w 1945 r. znalazły się w granicach ZSRR. Sytuacja zmieniła się dopiero w ostatnich latach, dzięki czemu na koniec autor mógł przedstawić pokrótce nowy kompleks upamiętniający ofiary obozu zagłady w Bełżcu, otwarty uroczyście 1 stycznia $2004 \mathrm{r}$.

Opracowanie Kuwałka dowodzi, że wiele podstawowych faktów na temat Zagłady, szczególnie na poziomie lokalnym, wymaga nadal ustalenia. Odwołanie się do relacji ocalałych pozwoliło autorowi stworzyć monografię o ośrodku masowej zagłady bez uprzedmiotowienia ofiar ${ }^{6}$. Książka ma charakter żmudnej rekonstrukcji wszystkiego, co dotyczyło obozu zagłady w Bełżcu. Nie tylko pogłębia naszą wiedzę o tym obozie, jego ofiarach i katach oraz o świadkach dokonującej się tam

${ }^{5}$ Zob. Jonathan Huener, Auschwitz, Poland and the Politics of Commemoration, 19451979, Athens: Ohio University Press, 2003; Omer Bartov, Erased: Vanishing Traces of Jewish Galicia in Present-Day Ukraine, Princeton-Oxford: Princeton University Press, 2007; Martyna Rusiniak, Obóz zagłady Treblinka II w pamięci społecznej (1943-1989), Warszawa: Neriton, 2008; Zofia Wóycicka, Przerwana żałoba. Polskie spory wokót pamięci nazistowskich obozów koncentracyjnych i zagtady 1944-1950, Warszawa: Trio, 2009.

${ }^{6}$ Zob. Filip Friedman, Zagłada Żydów lwowskich, Łódź: Centralna Żydowska Komisja Historyczna, 1945, s. 32. 
zbrodni. Kuwałek włącza się pośrednio do dyskusji o ważnych kwestiach w badaniach nad losem Żydów w czasie drugiej wojny światowej, takich jak żydowskie strategie przetrwania w obliczu „ostatecznego rozwiązania”, a także rola inicjatywy lokalnej i instytucji uczestniczących w przeprowadzeniu Zagłady, „zwykłych ludzi”, którzy brali udział w masowych mordach, wreszcie reakcji polskich i ukraińskich sąsiadów na dokonującą się zbrodnię. Monografia Roberta Kuwałka jest jedną z najważniejszych książek o Zagładzie, jakie się ukazały ostatnio w Polsce.

Natalia Aleksiun 